Jeffrey Dudgeon, H. Montgomery Hyde: Ulster Unionist MP, Gay Law Reform Campaigner and Prodigious Author

\title{
David Shaw
}

\section{(2) OpenEdition}

1 Journals

\section{Édition électronique}

URL : https://journals.openedition.org/etudesirlandaises/12145

DOI : 10.4000/etudesirlandaises. 12145

ISSN : 2259-8863

\section{Éditeur}

Presses universitaires de Caen

\section{Édition imprimée}

Date de publication : 30 décembre 2021

Pagination : 162-166

ISBN : 978-2-84133-157-0

ISSN : 0183-973X

\section{Référence électronique}

David Shaw, « Jeffrey Dudgeon, H. Montgomery Hyde: Ulster Unionist MP, Gay Law Reform Campaigner and Prodigious Author », Études irlandaises [En ligne], 46-2 | 2021, mis en ligne le 17 décembre 2021, consulté le 03 novembre 2022. URL : http://journals.openedition.org/etudesirlandaises/12145 ; DOI : https://doi.org/10.4000/etudesirlandaises. 12145

\section{(c) (i) (2) (2)}

Creative Commons - Attribution - Pas d'Utilisation Commerciale - Partage dans les Mêmes Conditions 4.0 International - CC BY-NC-SA 4.0

https://creativecommons.org/licenses/by-nc-sa/4.0/ 
primary and secondary sources on multiple continents" (p. 243). That the author should feel the need to insert this final essay reminds us that History remains among the humanities, a science of the fragment that seeks to reconstruct the past as faithfully as possible, while acknowledging the usual limitations of the representations of events, be they based upon dry statistics, or more subjective testimonies. Hence the format of the book per se raises epistemological and methodological issues due to the hybrid object under scrutiny that oscillates between facts and the subjective representations of the same - more or less attainable and representable - facts through epistolary exchanges.

To cut a long story short, the great force of this highly readable book is that it individuates the usually great mass of Irish migrants, giving them back (partly but undeniably) their voices - frequently including their erratic spelling and idiomatic grammar -, - some of - their names and singular itineraries through life. It also allows the contemporary reader to draw parallels and devise a pattern of connections and repetitions in human history. In that respect, let us quote:

Compared to twenty-first-century air travel, their [i.e. Irish migrants'] voyages were dangerous and on a par with those faced by African migrants on the Mediterranean today. (p. 160)

In a word, the book underlines the wider framework, the bigger violent picture and the subtle cogwheels of global networks of interconnections that human history is based upon. Through this singular process of analysis of letters, "low-resolution refugees" (p. 238) of the past - and the present at that - may be seen as human individuals once again. No doubt this book will make a durable contribution to the increasingly important scientific field of migration studies.

Thierry RoBIN

\section{Jeffrey Dudgeon, H. Montgomery Hyde: Ulster Unionist MP, Gay Law Reform Campaigner and Prodigious Author, Belfast, Belfast Press, 2018, 56 p.}

The recent and somewhat chaotic decision to replace Arlene Foster with Edwin Poots, and his subsequent rejection in favour of Sir Jeffrey Donaldson MP, as the leader of the Democratic Unionist Party (DUP) has once again brought into sharp focus the social conservatism of the party and its membership. This was increased when he and the deputy leader of the DUP, Paula Bradley MLA, offered an apology for the homophobia previously displayed by the party and its membership. Whilst some have welcomed it as a significant moment, others have regarded it with more caution. It has been noted that this apology did not apologise directly for the comments made by Ian Paisley Jr. MP and former DUP MP, Iris Robinson. Further there was no apology or admonishment for the DUP founder, the Reverend Dr. Ian Paisley or his Save Ulster from Sodomy campaign. 
Despite events such as this, which consequently result in the occasional outbreak of interest in the British media, there remains a tendency by them to misconstrue wider unionism with the policy and pronouncements of the DUP. The result of this is commentary, which is narrow, poorly analysed, and lacks historical understanding. This is then bundled and gathered as expert opinion for transmission to the public, re-exported and returned to Northern Ireland as a poor reproduction of unionism in Northern Ireland. Their focus is rigidly fixed on the DUP and its resistance to social liberalisation. What is often overlooked is that social change has occurred in Northern Ireland regardless of the efforts of the DUP.

There is now a growing number of resources providing explanations for the failure of the DUP and its campaigns to prevent reform. The Institute of Irish Studies, University of Liverpool has shown that there is a unionism that exists beyond the confines of the DUP. ${ }^{1}$ Their evidence has joined a considerable body of work to show the heterogenous nature of unionism in Northern Ireland. However, prior to these new initiatives, Jeffrey Dudgeon, and Harford Montgomery Hyde were campaigning for sexual law reform, and revealing that unionism was far from a unified entity. Whilst this evidence continues to grow, the historical efforts of Jeffrey Dudgeon and Harford Montgomery Hyde remain largely unknown outside Northern Ireland.

Jeffrey Dudgeon was the crucial voice in the campaigns for the decimalisation of homosexuality in Northern Ireland. He would later recall just how few friends his campaign had at the time, with all the political parties in Northern Ireland refusing to support his efforts. ${ }^{2}$ When his victory in the European Court of Human Rights was discussed in the House of Commons, no MPs from Northern Ireland voted to support the court's decision. Dudgeon followed up his own interest in equality and reform producing studies of Roger Casement and made regular media contributions in Northern Ireland. Later, he would become a local councillor for the Ulster Unionist Party. For his efforts and services in favour of the LGBTQ community in Northern Ireland, he would later be appointed Member of the Order of the British Empire (MBE). Following the historical tracks of his campaigning he has turned his attention to Harford Montgomery Hyde.

Dudgeon's work is best viewed as an introduction to Hyde, an expanded print version of a lecture given by the author as part of the $50^{\text {th }}$ anniversary of the Wolfenden Report. It is part biography, part political analysis, and a plea for Hyde's efforts to be acknowledged outside Northern Ireland. It is also a call for unionism in Northern Ireland to acknowledge its own historical deafness.

Hyde came from a conventional, mercantile unionist family. His father was a linen merchant and Justice of the Peace. The family were solid Gladstonian Home Rulers and involved in Ulster Volunteer Force gun running. However, he

1. Institute of Irish Studies, University of Liverpool, “Civic Space”, online: https://www.liverpool. ac.uk/irish-studies/civic-space.

2. Jeffrey Dudgeon, "NIGRA $30^{\text {th }}$ Anniversary of Freedom/Emancipation Celebratory Dinner", 26 October 2012, online: https://jeffdudgeon.com/gay-rights. 
did not retain any attachment to his family's Protestantism. It is whilst at Queens University we get the first glimpses of the complexity of Hyde's character. Much to his parents' concern at Queens he would flirt with Catholicism but would bow to pressure from his parents and never became a convert.

Given such a family background, it remains unclear why Hyde became interested in homosexual law reform. Due to the sources available to him, Dudgeon does not manage to provide a thorough answer to this question. Hyde himself was heterosexual. Whilst studying law at Oxford he was familiar with and mixed with the gay community and enjoyed the freedom offered by the inter-war years during his time there. He occupied Oscar Wilde's rooms at Magdalen College, and even shared rooms with the spy Guy Burgess, who made no attempt to hide his own homosexuality. Later, as an MP, he would become allied with Robert Boothby (later Lord Boothby), another who had enjoyed the freedom of Oxford to express, more discreetly than Burgess, his own sexuality.

Prior to the Second World War he volunteered for the army reserve and served with both MI6 and the Intelligence Corps. His war service took him to Gibraltar, the United States, Bermuda, and was attached to Supreme Headquarters Allied Expeditionary Force in 1944. He was part of Allied Commission for Austria. He would end the war with the rank of Lieutenant Colonel. A title he would later use throughout his time in Westminster. After he left the army, he returned to his law career and revived his interest in history and biography. He also stepped up his attempts to become an MP.

Hyde outwardly appeared to fit neatly the accepted vision of what a unionist MP should look like. He had attended University, studied law, served with distinction during the war, and had aristocratic connections via previous employment as librarian and private secretary to the Marquess of Londonderry. However, his social liberalism and lack of religious belief appeared to make him a less than obvious choice for Ulster unionists. Further, aware of the social conservatism of his potential constituents, he kept secret his upcoming divorce and did not share this with his campaign team. In Northern Ireland there was a real lack of choice for progressives such as Hyde if they wished to gain a seat at Westminster. Although the Northern Ireland Labour Party was a significant voice at Stormont, they had no representatives in the House of Commons. The Labour Party refused to allow candidates to stand in Northern Ireland, so Hyde had few options available to him. The Ulster Unionist Party at this time continued to resemble the character of a movement rather than a modern political party. It was a party of patronage rather than procedure. The voices and divisions that would in the future fracture unionism at the time of his selection remained in the background. He eventually succeeded in gaining selection for Belfast North in 1950.

By 1954 his interest in the history of homosexuality and law reform was a matter of public record. He was regarded as an expert on Oscar Wilde and would make parliamentary interventions regarding homosexual law reform. He began to research and campaign for the full disclosure of the Casement diaries. His considerable effort regarding the Casement diaries and the Wolfenden Report 
initially attracted little attention in Northern Ireland. He also became a leading voice for the abolition of capital punishment. This support for the abolition of the death penalty did raise the hackles of some in his constituency as it coincided with the IRA border campaign. His contribution to the campaign to abolish the death penalty was recognised and praised by Tribune, something hard to imagine any unionist politician achieving today. Further support and approval were received from The Daily Mirror, The Times, and The Guardian.

Even though he could count on support from the British media, this did not stop his actions from coming under scrutiny in Northern Ireland. Pressure was slowly building on Hyde. He won the first phase of his reselection in 1959, and it appears that with this victory there was something of an assumption by Hyde that ratification would be a formality. He was in the West Indies when the ratification meeting was due to take place. He chose not to travel home, despite some noticeably clear warnings that his reselection was not secure. Hyde placed in faith in chair of the selection committee, hoping for the meeting to be postponed. This was an error of judgement as he misjudged the growing ill-feeling towards him within the committee. Hyde lost the vote by seventeen votes and was deselected. His feelings concerning the vote provide a hint to his character, regarding the committee decision not to postpone the meeting as a "rank discourtesy" (p. 38). His attempts to appeal to the Ulster Unionist Party to overturn the decision revealed that he had no friends with any significant power within the party. It was reported that his support of the Wolfenden Report was a significant reason in his deselection in 1959. After his deselection, he would continue to campaign for reform and for the disclosure of the Casement diaries. However, even if had not been deselected, he would not have been able to prevent the failure of Westminster to extend homosexual law reform to Northern Ireland. He would record his disappointment as Ulster MPs voted against the decriminalisation of homosexuality in 1967.

Dudgeon's examination of Hyde cannot strictly be regarding as a biography. The limitations of the records left by Hyde, as recognised by the author, prevent the construction of a true, extensive examination of Hyde. Despite these limitations, the complexity of Hyde's character deserves greater depth of analysis. He clearly had the latitude to enjoy a lifestyle of his own choosing at Oxford. Later, he would join the Orange Order and Freemasons for reasons of political pragmatism, never expressing much enthusiasm for either organisation. His colourful choice of associations even lasted until his death. At his funeral Tim Brinton MP gave the oration. Brinton was on the right of the Conservative Party and would later join UK Independence Party (UKIP). Dudgeon reveals to the reader a picture of a man who was a modern social reformer, who at the same time was delighted to be part of an older rakish world where those with similar appetites could mingle freely. It is a portrait of man with intense interests and who enjoyed the company of those who provided congenial conversation.

Many within unionism remain reluctant to recognise the complexity of their own history. They prefer to seek the warmth of a broad, mythical narrative. That element of political unionism that sought to exclude Hyde from its history still 
continues to make the same stereotype that was made when he was deselected in 1959. Outside Northern Ireland, the stereotype of unionism as reactionary and ultra-conservative remains and although many continue to show there are different facets to unionism, their voices still struggle to be heard. The real value of this book is not as critique or biography but as a challenge to the deafness of unionism to its own history.

David SHAw

\section{Susan O'Regan, Music and Society in Cork, 1700-1900, Cork, Cork Uni- versity Press, 2018, 364 p.}

Comme l'indique clairement son titre, cette monographie traite de la vie musicale à Cork aux XVIII ${ }^{e}$ et XIX ${ }^{e}$ siècles, périodes sur lesquelles les études de ce type sont quasi inexistantes. Pour mener à bien son projet, l'auteure a puisé à diverses sources historiques. L'imposante bibliographie, exclusivement en langue anglaise, comprend, certes, un très grand nombre d'ouvrages. Elle est surtout enrichie d'une multitude de journaux, périodiques, affiches et programmes de théâtres ou de concerts, complétés d'une collection de manuscrits conservés en divers lieux de la ville comme les archives cléricales locales, celles de la cathédrale Saint-Finbarr ou de sociétés savantes, académies ou établissements d'enseignement musical. Un appareil de près de 1200 notes est renvoyé par chapitre en fin de volume ce qui favorise une première lecture fluide mais demande, comme toujours dans ce mode de présentation, un va-et-vient entre les pages dès que l'on cherche à prendre connaissance de l'origine d'une référence. À cela s'ajoutent d'utiles index et tables diverses: illustrations, abréviations, termes musicaux et même un rappel des valeurs monétaires (livre, shilling, guinée). Les illustrations, on comprend aisément pourquoi, sont rares au XVIII siècle et apparaissent principalement dans les quatre derniers chapitres correspondant à la période la plus récente. Enfin, un plan du centre-ville de Cork permet de localiser seize principaux lieux de concerts et de pratique publique musicale dont une bonne part reste observable de nos jours.

Nous avons là un ouvrage à la documentation solide présenté en dix chapitres selon un ordre chronologique: la deuxième ville d'Irlande/les concerts publics au XVIII siècle / musique et Église jusqu'en 1820 / musique lyrique jusqu'en 1840 / musique de charité et de divertissement/ citadins talentueux, mobilité et opportunité, 1820-1840 / explosion culturelle, diversité de la scène musicale, 18301840 / la propagation de la pratique amateure, 1840-1870 / musique et catholicisme, 1800-1900 / un avenir glorieux.

Ce découpage à la fois thématique et historique correspond à l'histoire même de la cité portuaire qui jouit d'une position stratégique propre à attirer armateurs et négociants. Juxtaposition des Églises anglicane et catholique romaine, coexistence d'Irlandais et d'Anglais, bilinguisme et opposition de groupes sociaux qui se doivent 